\title{
Changes in pro-inflammatory cytokines in association with exposure to moisture-damaged building microbes
}

\author{
M.K. Purokivi*, M-R. Hirvonen\#, J.T. Randell*, M.H. Roponen\#, T.M. Meklin ", A.I. Nevalainen`, \\ T.M. Husman', H.O. Tukiainen*
}

Changes in pro-inflammatory cytokines in association with exposure to moisturedamaged building microbes. M.K. Purokivi, M-R. Hirvonen, J.T. Randell, M.H. Roponen, T.M. Meklin, A.I. Nevalainen, T.M. Husman, H.O. Tukiainen. (C)ERS Journals Ltd 2001.

ABSTRACT: Several epidemiological studies have described an association between adverse health effects and exposure to mould and microbes present in the indoor air of moisture-damaged buildings. However, the biochemical linkage between microbial exposure and the large variety of reported respiratory symptoms is poorly understood.

In the present study, the authors compared the respiratory symptoms, the production of inflammatory mediators interleukin (IL)-1, IL-4, IL-6, tumour necrosis factor- $\alpha$ (TNF- $\alpha$ ) and cell count in nasal lavage fluid and induced sputum samples of subjects working in moisture-damaged and control school buildings. The sampling was performed and the questionnaires were completed at the end of the spring term, at the end of the summer vacation (2.5 months), during the winter term and after a 1-week winter holiday.

The authors found a significant elevation of IL-1, TNF- $\alpha$ and IL-6 in nasal lavage fluid and IL-6 in induced sputum during the spring term in the subjects from the moisture-damaged school building compared to the subjects from the control building. The exposed workers reported sore throat, phlegm, eye irritation, rhinitis, nasal obstruction and cough in parallel with these findings.

The present data suggests an association between microbial exposure, and symptoms as well as changes in pro-inflammatory mediators detected from both the upper and lower airways.

Eur Respir J 2001; 18: 951-958.

\begin{abstract}
*Dept of Respiratory Medicine, Kuopio University Hospital, Finland. "Laboratory of Toxicology and "Laboratory of Environmental Microbiology, National Public Health Institute, Kuopio, Finland.
\end{abstract}

Correspondence: M.K. Purokivi, Dept of Respiratory Medicine, Kuopio University Hospital, P.O. Box 1777, FIN-70211 Kuopio, Finland. Fax: 35817172683

Keywords: Cytokines
induced sputum
moisture
mould
nasal lavage

Received: January 32001

Accepted after revision July 312001

This study was supported by The Academy of Finland, the Yrjö Jahnsson Foundation and The Finnish Work Environment Fund.
Several epidemiological studies have shown an association between adverse health effects and exposure to mould and microbes present in the indoor air in moisture-damaged buildings [1-4]. However, little is known about the biochemical link between microbial exposure and the large variety of reported respiratory symptoms. The authors' recent results point to an association between increased levels of pro-inflammatory cytokines in nasal lavage fluid, high prevalence of respiratory symptoms among occupants and exposure to microbes in mouldy buildings [5]. These results are supported by the authors' in vitro findings indicating that exposure to spores of mouldy house microbes, such as Streptomyces and Mycobacterium, induce significant time- and dose-dependent production of pro-inflammatory cytokines such as interleukin (IL)-6 and tumour necrosis factor- $\alpha(\mathrm{TNF}-\alpha)$ in both mice and human cells [6-9]. Moreover, an association between occurrence of asthma or wheezing and skinprick test reactivity to moisture-indicative moulds has been reported in children attending mouldy school buildings, although skin-test positivity to moulds is relatively rare [10].
Nasal and bronchial epithelium, in addition to acting as a physicochemical barrier, plays a crucial role in initiating and augmenting host-defence mechanisms by synthesizing a variety of inflammatory mediators including pro-inflammatory cytokines. IL-1 and TNF- $\alpha$ are the principal mediators of the host response towards infectious organisms, and they are also involved in repair processes in the nasal mucosa [11]. IL-6 has growth regulatory effects on many cells, and it is also an important cofactor in IL-4 dependent immunoglobulin (Ig)-E synthesis. IL-4 is a product of T-helper 2-derived lymphocytes, as well as eosinophils, and basophil and mast cell lineages. High levels of IL-1, TNF- $\alpha$ and IL- 6 have been reported in response to viral infections, allergic rhinitis and asthma [12-19]. Very low levels of IL-1, IL-6 and TNF- $\alpha$ [15-20] have been detected from samples of healthy subjects.

The present study compared respiratory symptoms, production of inflammatory mediators (IL-1, IL-4, IL-6, TNF- $\alpha$ ) and cell counts in nasal lavage fluid and induced sputum samples from subjects working in moisture-damaged and control school buildings during working and vacation periods. 


\section{Methods}

\section{Subjects}

Thirty-seven employees working in a school building with moisture damage and visible mould growth, and 23 employees from a control school building volunteered to participate in this study (table 1). The subjects were teachers and kitchen personnel from the schools. The studied school buildings are included in a larger study project (Finnish Research Programme on Environmental Health, The Academy of Finland), which aims to clarify moisture and mould problems in school buildings and health effects among occupants. The study was approved by the Ethical Committee of Kuopio University Hospital, Kuopio, Finland.

\section{Study protocol}

The subjects were contacted four times during the study. On each visit, they were interviewed and asked to fill in a one-page questionnaire concerning their current health. The first contact was in May, at the end of spring term, to evaluate the effect of a prolonged exposure period (January-May). The second time was in August at the end of summer vacation (June-August) to explore the effects of absence from the school buildings. The third sampling was carried out in February, when the ground in Finland is covered with snow, and thus effects of pollen and outdoor mould could be avoided. The fourth contact was in March after a 1-week winter holiday, to find out whether a short break in the exposure could cause changes in the inflammatory markers in nasal lavage fluid. At visits 1-3 nasal lavage fluid, induced sputum and a venous blood sample for eosinophil cationic protein (ECP), IgE and C-reactive protein (CRP) analyses were collected. On the fourth visit, only nasal lavage fluid was collected (fig. 1).

\section{Characterization of the microbial exposure in the buildings}

Both the moisture-damaged and the control school building were inspected for visible signs of moisture

Table 1. - Subject characteristics

\begin{tabular}{lcc}
\hline School & Moisture-damaged & Control \\
\hline Sex M/F & $8 / 29$ & $6 / 17$ \\
Age & $48(34-61)$ & $46(31-56)$ \\
Smoking & 2 & 0 \\
Atopy & 10 & 5 \\
Number of positive & & \\
skin-prick tests & & \\
$\quad$ Common allergens & 26 & 20 \\
$\quad$ Moulds & 8 & 1 \\
\hline
\end{tabular}

M/F: male/female; ${ }^{*}$ : mean wheel diameter $\geqslant 3 \mathrm{~mm}$ in skinprick test (SPT) to at least one common allergen; ${ }^{\top}$ : in moisture-damaged school three persons and in the control school one person had a positive SPT for moulds.

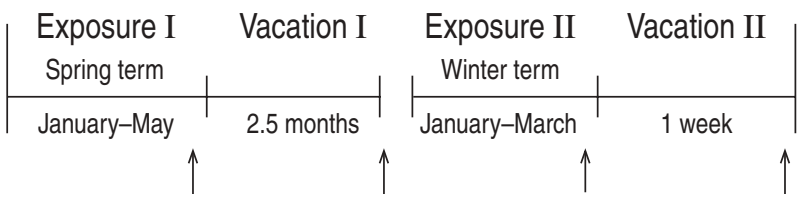

Fig. 1.-Study protocol. Questionnaires were completed and induced sputum and nasal lavage samples were collected at the end of exposure and vacation periods (arrows).

and mould growth by a civil engineer using a checklist and a surface moisture recorder. These assessments verified the damage history of the moisture-damaged school and the nondamaged status of the control school building. Concentrations of viable fungi, bacteria, and fungal flora were determined in the school buildings. Indoor air, surface and material sampling was performed in winter, when the ground was covered with snow and during working hours, when the buildings were occupied. Microbial samples from indoor air were collected with a six-stage impactor (Andersen 10-800, Graseby Andersen, Atlanta, Georgia, USA). The fungal samples were plated on $2 \%$ malt extract agar and on dichloran glycerol agar, whereas the bacterial samples were plated on tryptone glucose yeast agar. Seventeen samples were taken from the test school and 18 from the control school. The colonies on the incubated agar plates were counted as colony forming units $\left(\mathrm{cfu} \cdot \mathrm{m}^{-3}\right)$, and the fungi were identified morphologically to the genus level using a light microscope. The total concentrations of airborne bacteria and actinomycetes were counted from the bacteria samples. To complete the inspection samples of building material were collected from structures showing visible mould growth, as detected by the technical investigator, where dismantling of the structures was possible. Some surface samples were collected from the kitchens of both schools. These procedures have been described earlier $[21,22]$.

\section{Sputum induction}

Sputum was induced as previously reported, with inhalation of 4\% hypertonic saline for 5-20 min [20]. The collected sputum samples were examined within $2 \mathrm{~h}$ to avoid cell destruction [23]. Total cell count was determined using a haemocytometer and cell viability was analysed with the trypan blue exclusion method. The supernatant was aspirated and frozen at $-70^{\circ} \mathrm{C}$.

\section{Nasal lavage}

Nasal lavage was performed as described earlier [24] with some modifications [5]. Briefly, $4.5 \mathrm{~mL}$ of prewarmed Hank's balanced salt solution $\left(37^{\circ} \mathrm{C}\right)$ was instilled through a heat-softened catheter into the naris, while the subject held their chin down towards the chest and held the catheter in place by pinching the nares closed. Then the fluid was refluxed three times, and the cartilaginous bridge of the nose was vibrated by a paediatric precursor. The procedure was repeated 
in the opposite naris. The lavage fluid was collected and placed immediately on ice until processing.

\section{Biochemical analyses}

From the sputum supernatant ECP $\left(\mu \mathrm{g} \cdot \mathrm{L}^{-1}\right)$ was analysed by radioimmunoassay (RIA, Pharmacia \& Upjohn, Uppsala, Sweden). Cytokines were analysed from sputum and nasal lavage supernatants by using human IL-1, IL-4, IL-6 and TNF- $\alpha$ Duoset enzymelinked immunosorbent assay (ELISA)-kits obtained from Genzyme (Cambridge, MA, USA), and read by ELISA reader (iEMS Reader MF, Labsystems, Helsinki, Finland) at a wavelength of $450 \mathrm{~nm}$. Cytokine concentrations of samples were calculated by interpolating absorbances of samples to the standard curve.

\section{Cytospin}

The cell pellet of induced sputum was resuspended in phosphate buffered saline (Dulbecco's phosphate buffered saline, D-PBS, Life Technologies Ltd, Paisley, Scotland) to reach a concentration of $1 \times 10$ E6 cells $\cdot \mathrm{mL}^{-1}$. The cell suspension was centrifuged at $19 \times g(450$ revolutions per minute $(\mathrm{rpm})$ Shandon centrifuge, Life Sciences, International Ltd, Cheshire, UK). The slides were fixed in ethanol and stained with May-Grünwald Giemsa (MGG) for cell differential count from 500 cells. Only samples with cell viability $>50 \%$ and squamous cell contamination $<20 \%$ were included in the analysis [25]. The cytocentrifuge preparations of nasal lavage fluid were made by using $100 \mu \mathrm{L}$ of resuspended cell suspension, in which the mucus was broken by $0.5 \%$ dithiotreitol/ $0.1 \%$ bovine serum albumin. The solution was centrifuged and the slides were also stained with MGG [26].

\section{Skin-prick tests}

Skin-prick tests were carried out with the ALK skin-prick test system (ALK Laboratories, Copenhagen, Denmark) with 14 common allergens (birch, alder, the three most common types of hay pollen, mugworth, dandelion, horse, dog, cat, cow, Dermatophagoides farinae, D. pteronyssimus, latex) and 13 moulds (Alternaria alternata, Aspergillus fumigatus, A. versicolor, Aureobasidium pullulans, Botrytis cinerea, Chaetomium globusum, Cladosporium herbarum, Geotrichum candidum, Mucor racemosus, Penicillium brevicompactum, P. expansum, Phoma herbarum, Trichoderma viride, Wallemia sebi). A mean wheal diameter of $3 \mathrm{~mm}$ or more was regarded as a positive result. At least one positive result with the skin-prick test was considered to mean atopy.

\section{Statistical analyses}

Preliminary data analyses revealed that the distributions of cytokine values obtained in this study were not normal, and therefore logarithmic transformations were used in paired t-tests (difference between the time points) and unpaired t-tests (difference between the schools). The Chi-squared test (difference between the schools) and McNemar test (difference between the time points) were used to analyse data concerning symptoms. Based on previous epidemiological data, one-sided significance $\mathrm{p}<0.05$ was considered adequate in symptom analyses.

\section{Results}

\section{Microbial exposure}

Microbial analyses confirmed the classification of the school buildings into the moisture-damaged test school and control school. There was a significant difference in the geometric means (29 and $6 \mathrm{cfu} \cdot \mathrm{m}^{-3}$, respectively) of the total concentrations of viable airborne fungi between the schools $(p=$ 0.0002). Microbes indicating moisture damage, such as A. fumigatus, Eurotium, Trichoderma, Ulocladium, Fusarium, Rhodotorula, Phialophora, Exophiala and actinomycetes [27] were found only in the moisturedamaged school.

\section{Symptoms}

At the end of exposure I and exposure II, the subjects working in the moisture-damaged school reported more respiratory and nonspecific symptoms than they did at the end of vacation I (table 2). This

Table 2. - Statistically significant differences in the number of reported respiratory and nonspecific symptoms among subjects from the moisture-damaged school after periods of exposure

\begin{tabular}{|c|c|c|c|c|c|c|c|c|}
\hline \multirow[b]{2}{*}{ Symptom } & \multicolumn{3}{|c|}{ Exposure I } & \multicolumn{2}{|c|}{ Vacation I } & \multicolumn{3}{|c|}{ Exposure II } \\
\hline & Yes & No & p-value ${ }^{\#}$ & Yes & No & Yes & No & p-value ${ }^{\#}$ \\
\hline Sore throat & 8 & 25 & 0.035 & 2 & 30 & & & \\
\hline Phlegm & 12 & 25 & 0.000 & 9 & 23 & & & \\
\hline Eye irritation & 11 & 26 & 0.031 & 4 & 28 & 8 & 17 & 0.063 \\
\hline Rhinitis & 16 & 21 & 0.019 & 6 & 26 & & & \\
\hline Nasal Obstruction & 19 & 18 & 0.046 & 9 & 23 & & & \\
\hline Cough & 9 & 28 & 0.029 & 5 & 27 & 11 & 14 & 0.055 \\
\hline
\end{tabular}

\footnotetext{
${ }^{\#}: \mathrm{p}<0.05$ was considered statistically significant.
} 
was not seen within the control group during exposure I, after vacation I, during exposure II nor after vacation II. However, due to the small number of subjects, no significant differences were detected between the subjects from the moisture-damaged and the reference schools.

\section{Production of pro-inflammatory cytokines}

Nasal lavage fluid. During exposure I, the concentration of nasal IL-1 ( $\mathrm{p}=0.037)$ (fig. 2) was significantly higher among the personnel of the moisture-damaged school building compared to the subjects from the control school. This difference could also be detected, when atopic subjects of both schools were excluded from the analyses.

The concentrations of nasal TNF- $\alpha(\mathrm{p}=0.008)$ and IL-6 ( $\mathrm{p}=0.046)$ of exposed workers were significantly higher during exposure I than after vacation I. However, when the measurements of subjects from the moisture-damaged and control schools were compared, the differences in nasal TNF- $\alpha$ and IL-6 did not reach statistical significance during exposure I. In the control group, the level of nasal IL-6 was higher during exposure I than after the vacation $I(p=0.003)$. (fig. 2).

IL-4 concentration was significantly higher among the subjects of the control school when compared to the moisture-damaged school at the end of vacation I $(p=0.021)$ and also during exposure II $(p=0.015)$. However, if atopic subjects were excluded from the analyses, no difference was detected in IL-4 concentrations between the groups at these time points.

After vacation II, no changes in IL-1 concentrations in nasal lavage fluid samples of those working in the moisture-damaged school were detected. TNF- $\alpha$ concentrations were significantly lower after vacation II than before this vacation $(\mathrm{p}=0.02)$. In contrast, IL-4 concentration increased during this period ( $\mathrm{p}=0.037)$. However, after exclusion of atopic subjects, the differences were not statistically significant. In the control group, IL-6 increased significantly during vacation II, and this was not affected by the presence of atopy. No significant differences between the schools were detected after vacation II in any cytokine concentration. (table 3).

Induced sputum. During exposure I, the IL-6 concentration in induced sputum was significantly higher
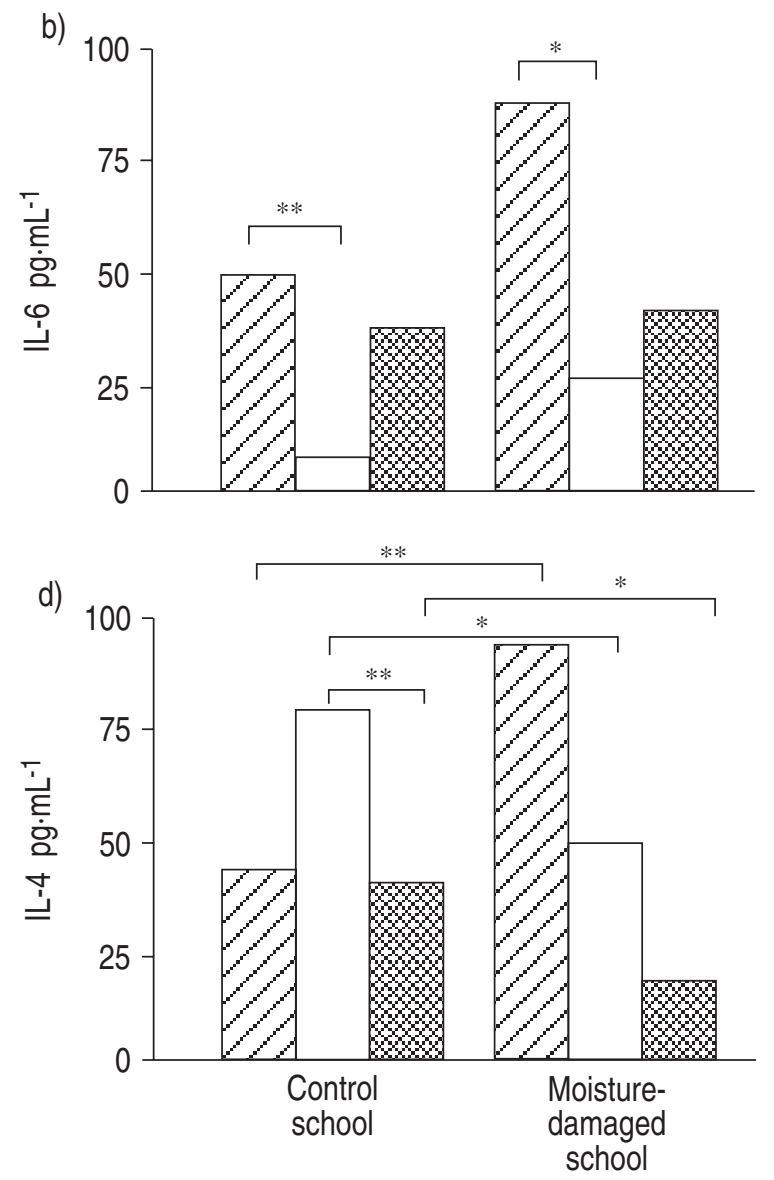

Fig. 2. - Concentrations of nasal cytokines a) interleukin (IL)-1; b) IL-6; c) tumour necrosis factor- $\alpha$; and d) IL-4 (arithmetic mean) at the end of exposure I $(\square)$, vacation I $(\square)$ and exposure II (장) in subjects from a moisture-damaged and control school. Unpaired t-tests were used to analyse differences between schools and paired sample t-tests were used between different time points. Logarithmic transformations were used in t-tests. ${ }^{*}: \mathrm{p}<0.05 ; * *: \mathrm{p}<0.01$. 
Table 3. - Tumour necrosis factor- $\alpha$ (TNF- $\alpha$ ), interleukin (IL)-1, IL-4 and IL-6 concentrations in nasal lavage and induced sputum

\begin{tabular}{|c|c|c|c|c|c|c|c|c|}
\hline \multirow[b]{2}{*}{ School } & \multicolumn{2}{|c|}{ Exposure I } & \multicolumn{2}{|c|}{ Vacation I } & \multicolumn{2}{|c|}{ Exposure II } & \multicolumn{2}{|c|}{ Vacation II } \\
\hline & $\begin{array}{l}\text { Moisture- } \\
\text { damaged }\end{array}$ & Control & $\begin{array}{l}\text { Moisture- } \\
\text { damaged }\end{array}$ & Control & $\begin{array}{l}\text { Moisture- } \\
\text { damaged }\end{array}$ & Control & $\begin{array}{l}\text { Moisture- } \\
\text { damaged }\end{array}$ & Control \\
\hline \multicolumn{9}{|c|}{ Nasal lavage } \\
\hline IL-1 & $\begin{array}{l}111(27) \\
(56.5)\end{array}$ & $\begin{array}{l}2.4(10) \\
(0.98)\end{array}$ & ND & ND & $\begin{array}{l}39.1(20) \\
(22.2)\end{array}$ & $\begin{array}{l}51.8(18) \\
(21.6)\end{array}$ & $\begin{array}{l}14.1(19) \\
(7.39)\end{array}$ & $\begin{array}{l}31.1(15) \\
(13.2)\end{array}$ \\
\hline IL-4 & $\begin{array}{l}92.7(28) \\
(24.6)\end{array}$ & $\begin{array}{l}40.9(12) \\
(13.4)\end{array}$ & $\begin{array}{l}47.8(32) \\
(15.6)\end{array}$ & $\begin{array}{l}79.0(19)^{* *} \\
(16.3)\end{array}$ & $\begin{array}{l}19.0(25) \\
(6.43)\end{array}$ & $\begin{array}{l}41.0(19) \\
(9.92)\end{array}$ & $\begin{array}{l}97.5(20) \\
(20.3)\end{array}$ & $\begin{array}{l}102(15) \\
(25.0)\end{array}$ \\
\hline IL-6 & $\begin{array}{l}85.7(28)^{*} \\
(46.6)\end{array}$ & $\begin{array}{l}44.2(12)^{* *} \\
(28.3)\end{array}$ & $\begin{array}{l}21.2(32) \\
(9.71)\end{array}$ & $\begin{array}{l}6.5(19) \\
(2.57)\end{array}$ & $\begin{array}{l}40.7(25) \\
(22.0)\end{array}$ & $\begin{array}{l}38.0(17)^{*} \\
(13.0)\end{array}$ & $\begin{array}{l}51(20) \\
(33.9)\end{array}$ & $\begin{array}{l}68.6(15) \\
(28.3)\end{array}$ \\
\hline TNF- $\alpha$ & $\begin{array}{l}91.2(28)^{* *} \\
(58.3)\end{array}$ & $\begin{array}{l}7.13(12) \\
(3.30)\end{array}$ & $\begin{array}{l}8.33(32) \\
(3.37)\end{array}$ & $\begin{array}{l}3.16(20) \\
(1.86)\end{array}$ & $\begin{array}{l}26.6(25) \\
(20.0)\end{array}$ & $\begin{array}{l}20.8(19) \\
(8.48)\end{array}$ & $\begin{array}{l}11.1(20) \\
(7.29)\end{array}$ & $\begin{array}{l}21.1(15) \\
(8.66)\end{array}$ \\
\hline \multicolumn{9}{|c|}{ Induced sputum } \\
\hline IL-1 & $\begin{array}{l}43.7(20) \\
(13.0)\end{array}$ & $\begin{array}{l}23.9(9) \\
(4.65)\end{array}$ & $\begin{array}{l}69.8(18)^{*} \\
(19.3)\end{array}$ & $\begin{array}{l}50.7(6) \\
(45.8)\end{array}$ & $\begin{array}{l}24.7(13)^{*} \\
(7.61)\end{array}$ & $\begin{array}{l}9.97(7) \\
(2.65)\end{array}$ & & \\
\hline IL-4 & $\begin{array}{l}38.6(22) \\
(10.4)\end{array}$ & $\begin{array}{l}20.3(9) \\
(7.20)\end{array}$ & $\begin{array}{l}50.7(19)^{* *} \\
(11.9)\end{array}$ & $\begin{array}{l}105(6)^{* * *} \\
(4.71)\end{array}$ & $\begin{array}{l}1.52(13) \\
(0.91)\end{array}$ & $\begin{array}{l}2.39(7) \\
(1.91)\end{array}$ & & \\
\hline IL-6 & $\begin{array}{l}37.3(22) \\
(8.47)\end{array}$ & $\begin{array}{l}5.45(9) \\
(2.44)\end{array}$ & $\begin{array}{l}49.1(19) \\
(12.1)\end{array}$ & $\begin{array}{l}27.1(8) \\
(16.8)\end{array}$ & $\begin{array}{l}31.8(13) \\
(10.3)\end{array}$ & $\begin{array}{l}6.70(7) \\
(2.52)\end{array}$ & & \\
\hline $\mathrm{TNF}-\alpha$ & $\begin{array}{l}1.32(22) \\
(0.80)\end{array}$ & $\begin{array}{l}1.00(10) \\
(0.55)\end{array}$ & $\begin{array}{l}0.80(19) \\
(0.32)\end{array}$ & $\begin{array}{l}0.60(6)^{*} \\
(0.21)\end{array}$ & $\begin{array}{l}1.0(13) \\
(0.81)\end{array}$ & $\begin{array}{l}<1(7) \\
(<1)\end{array}$ & & \\
\hline
\end{tabular}

Data are presented as mean $\mathrm{pg} \cdot \mathrm{mL}^{-1}$, the number of samples are in parenthesis beside the mean and SEM is in parenthesis below the mean; ND: not determined (not enough sample for analyses). Differences between time points (exposure I and vacation I, vacation I and exposure II, exposure II and vacation II) were analysed by paired sample t-test; *: p<0.05; **: $\mathrm{p}<0.01 ; * * *: \mathrm{p}<0.001$.

among the subjects working in the moisture-damaged school $(p=0.002)$ than that of the subjects from the control school (fig. 3). After vacation I, IL-1 ( $\mathrm{p}=0.052)$ and IL-4 $(\mathrm{p}=0.005)$ in induced sputum of subjects working in the moisture-damaged school, and TNF- $\alpha$ $(p=0.022)$ and IL-4 $(p=0.000)$ of the subjects from the control school were higher than those measured during exposure II. IL-4 concentrations in induced sputum were also significantly elevated $(p=0.012)$ among the control subjects during vacation I, when compared to the subjects of the moisture-damaged school. No difference in IL-4 was detected between the groups at the end of vacation I, when atopic subjects were excluded from analyses. During exposure II, levels of both TNF- $\alpha(p=0.131)$ and IL-6 $(p=0.110)$

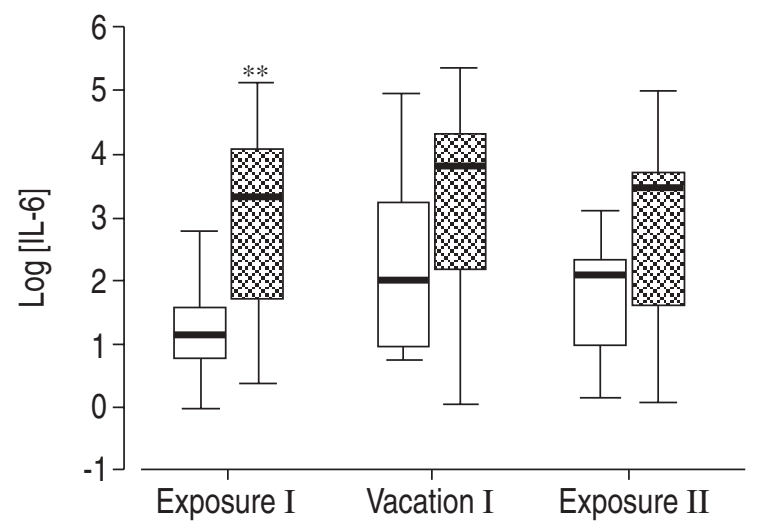

Fig. 3.-Concentrations (logarithmic values) of interleukin (IL)-6 in induced sputum from the subjects of the moisture-damaged ( $)$ and control $(\square)$ schools at different time points. ${ }^{* *}: \mathrm{p}<0.01$. Horizontal lines through the bars represent the median value. in the induced sputum of the subjects working in the moisture-damaged school were elevated when compared to the control group, but the difference did not reach statistical significance (table 3).

\section{Cell-differential count}

The relative share of lymphocytes, eosinophils and neutrophils in nasal lavage fluid did not differ between the subjects from the moisture-damaged and the control schools nor within the groups in the different time points, except at the end of vacation I, when nasal eosinophils in the personnel of the moisturedamaged school were significantly higher than during exposure II (arithmetic means 4.40 and 2.70 respectively, $\mathrm{p}=0.04$ ), However, this difference disappeared when atopic subjects were excluded from the analysis.

The induced sputum of the subjects working in the moisture-damaged school had a significantly higher number of macrophages $(\mathrm{p}=0.024)$ during exposure I than after vacation I. In contrast, the number of neutrophils in the end of vacation I was significantly $(\mathrm{p}=0.026)$ higher than during exposure I. Again, the statistical significance of the difference was lost when atopic subjects were excluded from the analyses (data not shown).

\section{Sputum eosinophil cationic protein}

ECP values in the subjects from the moisturedamaged school were significantly higher at the end of vacation I $\left(47.7 \mu \mathrm{g} \cdot \mathrm{L}^{-1}, \mathrm{p}<0.05\right)$ when compared to the values during exposure I $\left(26.7 \mu \mathrm{g} \cdot \mathrm{L}^{-1}, \mathrm{p}<0.05\right)$ or exposure II $\left(19.5 \mu \mathrm{g} \cdot \mathrm{L}^{-1}\right)$. This finding lost its 
statistical significance when the atopic subjects were excluded from the analyses. No such changes in the ECP levels were found within subjects from the control school, or between the subjects from the two schools. Furthermore, no significant difference was detected between schools in IgE or CRP values during the whole study period (data not shown).

\section{Discussion}

The present data point to an association between microbial exposure, reported symptoms, and the proinflammatory mediators assayed from both the upper and lower airways in subjects from a moisturedamaged school building. This is of particular interest because evidence of an association between moisturerelated mould growth in buildings and increased frequency of respiratory symptoms among the inhabitants or occupants was previously based largely on questionnaire studies [3]. There has been a serious lack of objective biochemical data concerning the inflammatory changes occurring in the respiratory tract mucosa of subjects exposed to microbial growth. In addition to increased production of pro-inflammatory cytokines in the nasal mucosa of the exposed individuals, the present study reports elevations in pro-inflammatory cytokine concentrations in induced sputum samples of individuals working in a moisturedamaged school with microbial growth confirmed by both technical building inspection and microbial assessment.

Although both sputum induction and nasal lavage are reproducible methods for studying inflammatory markers in airways [20], the wide variability in cytokine levels, especially during exposure periods, was noticed in samples from the personnel of the moisturedamaged school. This reflects differences in sensitivity against indoor air exposures among exposed subjects. The lower variability among control subjects supports this finding.

In the present study, both IL-1 and TNF- $\alpha$ were elevated in nasal samples during the first exposure period when compared to their levels during the summer holiday. This is in line with the authors' previous results showing the $\mathrm{TNF}-\alpha$ response in relation to working in a moisture-damaged building [5]. Interestingly, a vacation as short as a 7-day break in the winter term was long enough to significantly decrease the nasal TNF- $\alpha$ levels of exposed subjects. In concordance with the increased nasal TNF- $\alpha$ response, an elevation of TNF- $\alpha$ concentration in induced sputum was also detected during exposure II, although this did not reach statistical significance due to the small number of successful sample pairs. This is in line with the authors' in vitro findings, which demonstrate TNF- $\alpha$ elevation after exposure to actinomycetes and mycobacteria, both in mouse macrophages and a human lung epithelial cell line $[6,8]$. Low levels of TNF- $\alpha$ were detected at all time points in induced sputum samples from the control group, which agrees with previous findings [28]. Chronic, nonasthmatic cough has been reported to increase concentrations of TNF $-\alpha$ in induced sputum [29]. However, in this data, cough was frequent during exposure period I among subjects from the moisture-damaged school, but no significant elevation of $\mathrm{TNF}-\alpha$ in induced sputum could be detected.

IL-6 was elevated in both nasal and sputum samples in association with prolonged microbial exposure from the moisture-damaged building. Throughout the whole study period, IL-6 in induced sputum was lower in the control group than in the exposed group. This result supports the hypothesis that elevation of IL-1 and TNF- $\alpha$ in nasal lavage fluid as a result of exposure to indoor air microbes activates the production of IL-6 in the bronchial epithelium [16]. IL-6 is also known to suppress the inflammatory process by depressing the synthesis of IL-1 and TNF- $\alpha$, and also by inhibiting their expression and release from macrophages [30-32]. After vacation I, the IL-6 concentration in induced sputum among exposed subjects was higher than at other time points. However, the difference did not reach statistical significance.

Interestingly, after vacation I, IL-4 levels were significantly higher among the subjects from the control school in both nasal lavage fluid and induced sputum samples than the values measured from the subjects from the moisture-damaged school. In addition, the TNF- $\alpha$ level in the induced sputum of the control group and the IL-1 levels in induced sputum of the exposed group were higher in the end of vacation I than during exposure II. This may have been due to the relatively high outdoor pollen and mould levels in Finland in August, which may lead to the activation of atopic inflammation in airway mucosa and cause changes in IL-4 and TNF- $\alpha$ levels. The nasal eosinophil count in the exposed group was elevated after vacation I, but the differences disappeared, when atopic subjects of both study groups were excluded from the analysis. These findings point to the important role of eosinophils, IL-1, IL-4 and TNF- $\alpha$ in allergic inflammation $[15,33]$. There was no significant difference in the prevalence of atopy or positive skin-prick tests between the studied groups. Positive skin-prick test findings to moulds were rare, as reported earlier [10].

According to questionnaire data, few of the participants were living in moisture-damaged homes in either group, no difference between the groups being found. Furthermore, the number of pets did not differ between the groups. Thus, the reason for differences in IL-4 elevation is unlikely to be related to the home environment. The cold winter air as a cause of inflammation has previously been discussed [34], but its effect ought to be the same in both groups. Finally, the elevations in IL-1, IL-6 and TNF- $\alpha$ in nasal lavage fluid during exposure I were not affected by the exclusion of atopic subjects, which confirms that their role in inflammatory reactions was caused by indoor air bioaerosols.

The small number of successful cell counts between time points is likely to have an effect on the cell findings. The number of macrophages in the differential cell count of induced sputum was elevated among exposed subjects during exposure I. This finding also lost its statistical significance when atopic subjects were excluded from the analyses. 
Since the role of macrophages in allergic inflammation is well known, this observation further supports the view that the atopic subjects were more sensitive to indoor air microbes. However, to confirm this proposal, a larger series of repeated, paired induced sputum samples from the same subjects needs to be assayed.

The higher ECP values in the induced sputum of the exposed group, during exposure I and also after vacation I, are reflections of the elevated reactivity of eosinophils. Although a significant change in eosinophil count was detected only at the end of vacation I, the elevation of ECP most likely was related to the elevated levels of outdoor allergens during exposure I, as well as during vacation I in summer when ECP levels in the exposed group were highest (although there was no work-related mould exposure). Despite the changes in the IL-4 levels, no significant changes in total IgE levels were found at any time point, although IL-4 is known to activate B-lymphocytes and to promote IgE synthesis [35]. CRP levels were also low throughout the follow-up. This indicates that changes in pro-inflammatory cytokine concentrations were not attributable to infectious diseases.

The authors conclude that the changes in the concentrations of pro-inflammatory cytokines in nasal lavage and induced sputum samples at different time points provide evidence for an association between exposure to mouldy house microbes and the symptoms of the exposed subjects.

\footnotetext{
Acknowledgements. The authors thank the personnel of the school buildings for participation in the study. H. Martikainen, L. Heikkinen and R. Tukiainen are acknowledged for their excellent technical assistance, E. MacDonald for revising the language and $\mathrm{M}$. Vahteristo for help in statistical analyses.
}

\section{References}

1. Dales R, Burned R, Zwanenburg H. Adverse health effects among adults exposed to home dampness and molds. Am Rev Respir Dis 1991; 143: 505-509.

2. Pirhonen I, Nevalainen A, Husman T, Pekkanen J. Home dampness, moulds and their influence on respiratory infections and symptoms in adults in Finland. Eur Respir J 1996; 9: 2618-2622.

3. Koskinen $\mathrm{O}$, Husman T, Hyvärinen A, Reponen T, Nevalainen A. Two moldy day-care centers: a followup study of respiratory symptoms and infections. Indoor Air 1997; 7: 262-268.

4. Verhoeff AP, Burge A. Health risk assessment of fungi in home environments. Ann Allergy Asthma Immunol 1997; 78: 544-556.

5. Hirvonen M-R, Ruotsalainen M, Roponen $\mathrm{M}$, et al. Nitric oxide and proinflammatory cytokines in nasal lavage fluid associated with symptoms and exposure to moldy building microbes. Am J Respir Crit Care Med 1999; 160: 1943-1946.

6. Hirvonen M-R, Nevalainen A, Makkonen N, Mönkkönen J, Savolainen K. Induced production of nitric oxide, tumor necrosis factor, and interleukin-6 in RAW264.7 macrophages by streptomycetes from indoor air of mouldy houses. Arch Environ Health 1997; 52: 426-432.

7. Ruotsalainen $M$, Hirvonen M-R, Hyvärinen A, Meklin T, Savolainen K, Nevalainen A. Cytotoxicity, production of reactive oxygen species and cytokines induced by different strains of Stachybotrys sp. from moldy buildings in RAW264.7 macrophages. Environ Toxicol Pharmacol 1998; 6: 193-199.

8. Jussila J, Ruotsalainen M, Komulainen H, Savolainen K, Nevalainen A, Hirvonen M-R. Streptomyces anulatus from indoor air of moldy houses induce NO and IL-6 production in a human alveolar epithelial cell-line. Environ Toxicol Pharmacol 1999; 7: 261-266.

9. Huttunen K, Ruotsalainen M, Iivanainen E, Torkko P, Katila M-L, Hirvonen M-R. Inflammatory responses and cytotoxicity in RAW264.7 macrophages caused by mycobacteria isolated from indoor air of moldy houses. Environ Toxicol Pharmacol 2000; 8: 237-244.

10. Taskinen $\mathrm{T}$, Meklin $\mathrm{T}$, Nousiainen M, Husman T, Nevalainen A, Korppi M. Moisture and mould problems in schools and respiratory manifestations in school children: clinical and skin test findings. Acta Paediatrica 1997; 86: 1181-1187.

11. Min Y-G, Rhee C-S, Kwon S-H, Lee KS, Jung JB. Effects of IL-1beta, TNF-alpha, and TGF-beta on proliferation of human nasal epithelial cells in vitro. Am J Rhinology 1998; 12: 279-282.

12. Arnold R, Humbert B, Werchau H, Gallati H, König W. Interleukin-8, interleukin-6, and soluble tumour necrosis factor receptor type I release from a human pulmonary epithelial cell line (A549) exposed to respiratory syncytial virus. Immunology 1994; 82: 126-133.

13. Bachert C, Wagenmann M, Hauser U. Proinflammatory cytokines: measurements in nasal secretion and induction of adhesion receptor expression. Internat Arch Allergy Immunol 1995; 107: 106-108.

14. Becker S, Quay J, Soukup J. Cytokine (tumor necrosis factor, IL-6, and IL-8) production by respiratory syncytial virus-infected human alveolar macrophages. J Immunol 1991; 147: 4307-4312.

15. Calderon MA, Devalia JL, Prior AJ, Sapsford RJ, Davies RJ. A comparison of cytokine release from epithelial cells cultured from nasal biopsy specimens of atopic patients with and without rhinitis and nonatopic subjects without rhinitis. J Allergy Clin Immunol 1997; 99: 65-76.

16. Cromwell O, Hamid Q, Corrigan CJ, et al. Expression and generation of interleukin-8, IL-6 and granulocytemacrophage colony-stimulating factor by bronchial epithelial cells and enhancement by IL-1beta and tumour necrosis factor- $\alpha$. Immunology 1992; 77: 330337.

17. Kenney JS, Baker C, Welch M, Altman LC. Synthesis of interleukin-1alpha, interleukin-6, and interleukin-8 by cultured human nasal epithelial cells. J Allergy Clin Immunol 1994; 93: 1060-1067.

18. Mullol J, Xaubet A, Gaya A, et al. Cytokine gene expression and release from epithelial cells. A comparison study between healthy nasal mucosa and nasal polyps. Clin Exp Allergy 1994; 5: 607-615.

19. Sousa AR, Lane SJ, Nakhosteen JA, Lee TH, Poston RN. Expression of interleukin-1 Beta (IL-1b) and interleukin-1 receptor antagonist (IL-1ra) on 
asthmatic bronchial epithelium. Am J Respir Crit Care Med 1996; 154: 1061-1066.

20. Purokivi M, Randell J, Hirvonen M-R, Tukiainen H. Reproducibility of measurements of exhaled NO, and cell count and cytokine concentrations in induced sputum. Eur Respir J 2000; 16: 242-246.

21. Hyvärinen A, Reponen T, Husman T, Ruuskanen $\mathrm{J}$, Nevalainen A. Characterizing mold problem buildings - concentrations and flora of viable fungi. Indoor Air 1993; 3: 337-343.

22. Nevalainen A, Partanen P, Jääskeläinen E, et al. Prevalence of moisture problems in Finnish houses. Indoor Air 1998; 4: 45-49.

23. Popov T, Gottschalk R, Kolendowicz R, Dolovich J, Powers P, Hargreave FE. The evaluation of a cell dispersion method of sputum examination. Clin Exper Allergy 1994; 24: 778-783.

24. Graham DE, Koren HS. Biomarkers of inflammation in ozone-exposed humans. Comparison of the nasal and bronchoalveolar lavage. Am Rev Respir Dis 1990; 142: $152-156$

25. Popov TA, Pizzichini MMM, Pizzichini E, et al. Some technical factors influencing the induction of sputum for cell analysis. Eur Respir J 1995; 8: 559-565.

26. Prat J, Xaubert A, Mullol J, et al. Immunocytological analysis of nasal cells obtained by nasal lavage: a comparative study with a standard method of cell identification. Allergy 1993; 48: 587-591.

27. Samson R, Flannigan B, Flannigan M, Verhoeff A, Adan O, Hoekstra E, eds. Recommendations, Health Implications of Fungi in Indoor Environments. Vol. 2. Amsterdam, Elsevier B.V., 1994.

28. Gelder CM, Thomas PS, Yates DH, Adcock IM, Morrison JFJ, Barnes PJ. Cytokine expression in normal, atopic, and asthmatic subjects using the combination of sputum induction and the polymerase chain reaction. Thorax 1995; 50: 1033-1037.

29. Jatakanon A, Lalloo GL, Sam L, Chung KF, Barnes PJ. Increased neutrophils and cytokines, TNF- $\alpha$ and IL-8, in induced sputum of non-asthmatic patients with chronic dry cough. Thorax 1999; 54: 234-237.

30. Schindler R, Mancilla J, Endres S, Ghorbani R, Clark $\mathrm{SC}$, Dinarello CA. Correlations and interactions in the production of interleukin-6 (IL-6), IL-1, and tumor necrosis factor (TNF) in human blood mononuclear cells: IL-6 suppresses IL-1 and TNF- $\alpha$. Blood 1990; 75: 40-47.

31. Ulich TR, Guo K, Remick D, del Castillo J, Yin S. Endotoxin-induced cytokine gene expression in vivo III IL-6 mRNA and serum protein expression and the in vivo hematologic effects of IL-6. J Immunol 1991; 146: 2316-2323.

32. Ulich TR, Yin S, Guo K, Yi ES, Remick D, del Castillo J. Intratracheal injection of endotoxin and cytokines II interleukin-6 and transforming growth factor beta inhibit acute inflammation. Am J Pathol 1991; 138: 1097-1101.

33. Keatings VM, Collins PD, Scott DM, Barnes PJ. Differences in interleukin-8 and tumor necrosis factor alpha in induced sputum from patients with chronic obstructive pulmonary disease or asthma. Am J Respir Crit Care Med 1996; 153: 530-540.

34. Larsson K, Tornling G, Gavhed D, Muller-Suur C, Palmgren I. Inhalation of cold air increases the number of inflammatory cells in the lungs in healthy subjects. Eur Respir J 1998; 12: 825-830.

35. Vercelli D, Jabara H, Arai K, Yokota T, Geha R. Endogenous interleukin 6 plays an obligatory role in interleukin 4-dependent human IgE synthesis. Eur J Immunol 1989; 19: 1419-1424. 